\title{
A comparison between two migrations in the Byzantine Empire: the Goths and the Pechenegs
}

\section{Alexandru Madgearu}

\begin{abstract}
:
The study compares from several points of view two migratory movements across the Lower Danube: the Tervingi Goths in 376 and the Pechenegs in 1045-1047. In both cases the imperial authorities hoped they would gain supplementary military forces, but the events turned both migratory groups into internal enemies. There are some similarities in the causes of the aforementioned migrations, in the way the Danube was crossed, and as concerns the places granted for settlement, and the integration in the Roman / Byzantine army. In other respects, the movements differed, especially because of the nomadic type of life of the Pechenegs, the Goths being sedentary people who moved from a homeland to another. Both migrations had disastrous effects for the empire, because the emperors were not able to foresee or to prevent the rebellions of these warrior people received as refugees. Instead of more economic and military resources, both the Goths and the Pechenegs caused much trouble in the South-East European provinces.
\end{abstract}

History does not repeat itself, but there are some events which display similarities worth investigating. For an empire whose northern limit on the Danube was not only geographic, but also the edge of civilization, its crossing by crowds of warriors was certainly something difficult to cope with. In both cases, the emperors and the local commanders were involved in actions aimed to resolve by agreement a security issue appeared along the frontier. In both cases, the final result was unexpected and disastrous for the empire. The first migration was that of the Tervingi Goths. Driven away by the Huns at the end of 375 from their homeland west of Dniester, after some fights, they begged for asylum in the empire. The migration over the Danube occurred in the spring of 376, was led by Fritigern and Alaviv, two representatives of the philo-Roman party of the Gothic aristocracy. In the spring of 377 came the second group, led by Alatheus and Safrax, the rulers of the Greuthungi Goths (the first victims of the Hunic invasion). The other migration started in 1045, when a part of the Pecheneg population sought refuge after a fratricide conflict. The chief Kegen who rebelled against the supreme chief Tyrach found a sheltered area in the swamps of the Danube (Balta Borcea) for the people who followed him. From there, he asked to be received in the empire. In the second part of this migration (1047), Tyrach moved with the bulk of the Pecheneg population. 
These are, shortly speaking, the migrations which will be compared. The sources are detailed enough to provide us with a good understanding of the facts. For the Tervingian migration and for its consequences up to the battle of Adrianople ( $9^{\text {th }}$ August 378), the most important is the history of Ammianus Marcellinus (book XXXI). Other data are recorded in the works of Zosimos (IV, 20-24), Eunapios (De Legationibus, fragment 42), Orosius (VII, 33. 10-15), Socrates Scholasticos (IV, 33-34, 38), Sozomenos (VI, 37, 40), Philostorgios (IX, 17), Jordanes (131-138), and Theophanes Confessor (AM 5869-5870). Only Ammianus Marcellinus and Eunapios were contemporary with the events, and they provided the most detailed descriptions. Unfortunately, the work of Eunapios is preserved only in some fragments (Zosimos copied the data from that history). The other sources give only abridged accounts of the events occurred between the crossing of the Danube and the battle of Adrianople. Even Jordanes, who wrote the history of his Gothic people, was not so much concerned with them. The history of John Malalas, much read by the Byzantines, ignored the Gothic migration in the empire and the following fights. It is most likely that the large universal history of John of Antioch included a chapter about these events, but this work survived only in scattered fragments. The Pecheneg migrations of 1045-1047 and their aftermath are described in the histories of Michael Psellos, Michael Attaliates, Ioannes Skylitzes and Ioannes Zonaras, and in a different kind of source, the speeches of the metropolitan bishop of Euchaita Ioannes Mauropous delivered to the emperor Constantine IX. In this case there are a contemporary source (Mauropous) and two quite close to the events, the histories of Psellos and Attaliates. Besides the literary sources, some data about the Pecheneg chiefs (their positions in the Byzantine army) are provided by their lead seals.

\section{Cause of migrations}

Both migrations were the last act of larger movements started far away in Central Asia. The Huns, who were displaced by the Ogurs from their homeland in the Syr-Daria region around 350, began their migration to the west, reaching the lower Don region peopled by the Alans around 370. After few years, the Huns and the Alans moved to the west, pushing the Greuthungi Goths. In 375, the Huns and their allies were already on the Dniester line, soon abandoned by the Tervingi who fled toward the Danubian limes after a failed attempt to erect an earthen wall ${ }^{1}$. In the case of the Pechenegs, the chain reaction occurred only in the second stage of the migration, in 1047, when the largest group led by Tyrach

1 Ammianus Marcellinus, XXXI, 2-3 (p. 98-108); Czeglédy 1983, p. 33-34, 65-82. 
was pushed by the Uzi, who were in their turn driven away by the Cumans (they are the Getae mentioned by Michael Psellos with an archaic name) ${ }^{2}$. The chain reaction found both peoples divided in factions. Amongst the Tervingi, the attitude toward the Romans was the reason of the fratricide fights. The Gothic aristocracy was divided in two parts, one pro-Roman and pro-Christian, and another one traditional, who was still heathen and hostile to the Romans. The chief Fritigern, who promised to protect the persecuted Christians, received military help from emperor Valens. King Athanarich managed to keep the power after the civil war of 369-372, but the discord persisted, and in this state the Goths were hit by the Hunnic invasion ${ }^{3}$. In the case of the Pechenegs, the position of the supreme leader Tyrach was challenged by an ambitious ruler who found his salvation in refuge, where he became the ally of the Byzantine Empire. The migration was the effect of this rebellion against Tyrach. This was a good opportunity for the emperor to apply to Pechenegs the usual policy of divide et impera. Kegen took revenge against Tyrach after the establishment in Paradunavon launching several campaigns in his territory and taking prisoners. This was seen by Tyrach as a violation of the existing treaty between the Empire and the Pechenegs, established in 1036, but the emperor chose to support Kegen's people, who were already his subjects ${ }^{4}$. In both cases, these internal quarrels weakened the resistance of those who remained north of the Danube (when the Huns attacked Gothia, and when the Uzi started their migration in the Pecheneg land).

\section{The crossing of the river}

The Danube has several fords which were used in antiquity and the middle ages for transportation, trading, but also for military actions and migrations. The most important are those from Isaccea (ancient Noviodunum), Hârşova (ancient Carsium), Dervent (ancient Sucidava) and Silistra (ancient Durostorum, medieval Dristra). At least three of them (Isaccea, Dervent and Silistra) were used in the migrations discussed in this paper. For the first Gothic group, the Danube was at a short distance from the place where the final battle against the Huns was fought (somewhere near the mouths of Siret and Prut rivers) 5 . This would imply that the first mass of refugees gathered most probably on

2 Michael Psellus, VII, 67 (p. 212); Jean Skylitzès, Constantin Monomachos, 16 (p. 377-378); Spinei 2006, p. 283-284.

3 Socrates, IV. 33.1-3 (p. 187); Wolfram 1988, p. 69-70; Lenski 1995, p. 51-67; Chauvot 1998, p. 201-204, 257-260.

4 Jean Skylitzès, Constantin Monomachos, 17 (p. 379).

5 Madgearu 2011, p. 94-95. 
the bank in front of the sector of the limes between Dinogetia and Arrubium, where the Danube is very large. There were no fords there, and Roman boats were used for crossing. The unexpected large number of refugees created mayhem. The boats were not enough, and some of the people drowned. For the following part of the migration of the Tervingi, which was more organized, it should be supposed that the refugees were received by usual crossing points like Sucidava and Durostorum. Later on, the Greuthungi crossed the Danube by Noviodunum, the nearest ford to their country. The fords of Sucidava (unknown name in the middle Byzantine period) and Dristra were certainly those used by Kegen's people, because they gathered before the crossing in the swamps located between these fortresses (the so-called Balta Borcea). In the case of the second group of the Pechenegs, the freezing of the river in the winter of 1046/1047 made its crossing possible along wider sectors, not only by the defended fords. As John Mauropous wrote, they entered all the land beyond the river because the Danube was frozen. The invasions covered a large part of the frontier ${ }^{6}$. The same information about the crossing during frost was recorded by Michael Psellos. This second invasion involved much more Pechenegs than in 1045, when they had migrated through one or at most two places (Dervent and perhaps Dristra).

\section{Sedentary / nomadic people}

The Visigoths were sedentary people who practiced agriculture and lived in villages not too different from those of the inhabitants of the empire. Their migration in what was called Gothia was a slow process of expansion of sedentary communities. These Germanic people commenced a cohabitation with the existing sedentary population. The archaeological expression of this multi-ethnic society is the Sântana de Mureş-Černjachov culture. The mass migrations of the Gothic families from this homeland over the Danube were determined only by the advance of the Huns. Ammianus Marcellinus (XXXI. 3. 7) specified that one reason of the refuge in the empire, besides the shelter offered by the Danube, was the fertile land, where they hoped to continue to practice agriculture like in the regions from where they were displaced. The first group led by Fritigern and Alaviv received such lands at the order of the emperor (XXXI. 4. 8). Contrary to the Goths, the Pechenegs were true nomads. Even if they were too chased by the Uzi, the migration across the Danube was something ordinary for their way of life. The conversion to sedentary life occurred only after their settlement in the empire, in the so-called Patzinakia, because the Byzantine authorities decided to transform the Pechenegs into common inhabitants of the peripheral province,

${ }^{6}$ Iohannis Euchaitorum metropolitae, p. 144 (nr. 182). 
giving them places to live. The name Patzinakia appears on the seal of its ruler, Kegen. It was located in the region near Preslav called Hekaton Bounoi, a field rich in meadows, forests and rivers. ${ }^{7}$ The conversion to sedentary life is shown by the archaeological discoveries, especially by those from Odărci (the cemetery of a Pecheneg village, with 535 graves). ${ }^{8}$ The settlement was also decided for those Pechenegs ruled by Tyrach who were defeated by the Byzantine army and the troops of Kegen. The duke of the Bulgarian theme, Basil Monachos, ordered that they will be colonized between Serdica (Sofia), Naissos (Niš) and Eutzapolis (Ovče Pole), where they started to practice agriculture'. Herding cattle continued to be the foremost occupation, in places suitable for grazing from north-eastern Bulgaria (Deliorman).

\section{Settlement places in the empire}

The Goths and the Pechenegs were settled in places partially depopulated by previous attacks of the same or other invaders, in the same peripheral province called Moesia Secunda in the $4^{\text {th }}$ century and Paradunavon in the $11^{\text {th }}$ century. For the first Gothic migration, Eunapios mentioned a total of almost 200,000 refugees who wished to cross the Danube ${ }^{10}$, but it is not known how many succeeded in entering the empire. For the second migration there are no such data. The figure given by Eunapios seems to be reliable, since it includes the family members. The number of 800,000 Pechenegs mentioned by Skylitzes is obviously exaggerated ${ }^{11}$ and maybe it should be corrected to 80,000 (including families). Marek Meško tried to estimate the maximum number of Pechenegs that could settle in the entire province of Paradunavon according to the available grazing areas for horses and cattle. Because a horse needs 10 hectares during a year, that region of 55,000 square $\mathrm{km}$ could support at most 250,000 horses and 50,000 Pechenegs ${ }^{12}$. This analysis leaves away those Pechenegs who became sedentary. The Gothic refugees were settled in various places in the Thracian diocese, in small groups, in order to prevent the rebellions. They became colons on imperial or private estates ${ }^{13}$. The first group of Pechenegs, the refugees, enjoyed a special status of autonomy in Patzinakia. Only the prisoners taken in

7 Jordanov 2009, p. 465-466, nr. 1380; Fiedler 2013, p. 250-252. For Hekaton Bounoi: Diaconu 1970, p. 66-69, 73-76; Schmitt 2006, p. 482; Meško 2013, p. 197.

8 Dončeva-Petkova 2013, p. 227-246; Curta 2013, p. 170-177; Fiedler 2013, p. 261-267.

9 Jean Skylitzès, Constantin Monomachos, 17 (p. 380); Curta 2013, p. 148-149.

10 Blockley 1983, p. 60-61 (frg. 42).

11 This is also sustained by Diaconu 1970, p. 62 (perhaps 100.000); Malamut 1995, p. 118; Spinei 2006, 190; Meško 2012, p. 19.

12 Meško 2012, p. 20-22.

13 Cesa 1984, p. 71. 
1047 were dispersed without weapons in various places, in order to pay tribute and to be used as soldiers, when needed ${ }^{14}$. The Pechenegs kept their autonomous territory, and remained peaceful until the onset of the secessionist movement of Paradunavon in 1072.

\section{The authorities' attitude}

The decision for the admission of the Tervingi was delayed for several months, until the arrival of the order given by Valens, who was then in Antioch. The emperor was advised to receive as many barbarians as possible on the Roman soil for military and economic reasons. He needed supplementary forces. Messengers were dispatched to the lands north of the Danube to gather them and to direct them to the limes (Amm. Marc. XXXI, 4.4; Eunapios, frg. 42) ${ }^{15}$. In the case of the Pechenegs, the decision to receive them in the empire was taken by the emperor Constantine IX immediately after the message sent by the duke of the Danubian province, Michael. Kegen was invited to Constantinople as a ruler of his people. He received the title of magistros. Tyrach too, after his defeat, was well received by the emperor. He became Christian in similar conditions like Kegen. He was appointed eparchos (the title is mentioned on his seal found at Vetren) ${ }^{16}$. This function could concern the leadership over the Pechenegs that were colonized in the empire after the defeat. Kegen's Pechenegs became symmachoi, which means that they were considered allies of the empire (they came as a ready to fight army, not like the Visigoths, who run after a major defeat). This kind of relationship was quite similar to the Roman foedus. The granting of three fortresses on the frontier to these newcomers was without precedent. After the battle at Preslav (1053), Constantine IX concluded another peace treaty for 30 years with the Pechenegs, who were again considered symmachoi. ${ }^{17}$

If the status of the Pechenegs is clear (they were symmachoi), for the Goths the present historiography has not reached a final conclusion. One opinion sustains that they were received in empire as dediticii ${ }^{18}$. Deditio was the unconditioned capitulation with no weapons preservation. The deditio was applied in the past for other Goths, in 278, as well as for the Bastarns, in $280^{19}$. In both cases, the emperor Probus aimed to obtain security along the frontier and a

${ }_{14}$ Jean Skylitzès, Constantin Monomachos, 17 (p. 380).

15 Wolfram 1988, p. 72; Kulikovski 2007, p. 129.

16 Atanasov, Jordanov 1994, 41; Spinei 2006, p. 191.

17 Jean Skylitzès, Constantin Monomachos, 28 (p. 392); Diaconu 1970, p. 75; Schmitt 2006, p. 484485.

18 Cesa 1984, p. 70; Wolfram 1988, p. 117-118; Wirth 1997, p. 47-48.

19 Histoire Auguste, Probus, XVI. 3, XVIII, 1 (p. 34, 35). 
buffer space across it. These operations were perhaps in the mind of those who advised Valens to act in the same way. Orosius (VII, 33.10) believed that the first group of the Gothic warriors was received in the empire without a treaty and with the preservation of their weapons. According to Eunapios, the agreement specified that the Goths will enter without weapons, but the migrants were able to take them because they were not properly watched when they crossed the limes. All these would indeed suggest a deditio. However, Peter Heather observed that the best source, Ammianus Marcellinus, did not mention the absence of the weapons, and that the information given by Eunapios was mistaken. He also pointed out that the refugees were able to choose where they would settle. ${ }^{20}$ Therefore, it seems more probable that the first group of Tervingi received the status of foederati (the Greuthungi crossed the Danube without any agreement, illegally, when the Roman authorities were already overwhelmed by the first migration movement).

In the case of Tervingi, the official attitude toward the refugees was undermined by the behavior of the local authorities. The greed of Maximus, the $d u x$ of one of the provinces Moesia Secunda or Scythia, and of Lupicinus, comes of the army of the Thracian diocese, led to starvation and to horrendous acts fulfilled by the Romans against the poor refugees, like selling dogs to be eaten in exchange for slaves (Amm. Marc. XXXI. 4. 9; Orosius, VII, 33. 11; Iordanes, 134-135). Later on, the same Lupicinus organized a plot against Fritigern and Alaviv, who were living in Marcianopolis, but he failed, being too attacked by the Goths. (Amm. Marc, XXXI, 5. 5-9, Iordanes, 136-137, Eunapios, fr. 42). Such bad treatment is not attested for the Pecheneg refugees, and it could even be said that Kegen's people, by the mere act of Christianization, became equal to the other inhabitants of the empire, with their own chief recognized by the emperor. This was a major difference between the two migrations.

Socrates, who specified that Valens hoped that the Goths would be a valuable new army for the defence of the frontiers, wrote that "the barbarians having been put into possession of Thrace, and securely enjoying that Roman province, were unable to bear their good fortune with moderation; but committing hostile aggressions upon their benefactors, devastated all Thrace and the adjacent countries" ${ }^{\prime 2}$. In this phrase we can find a concentrated relation about the fate of the agreement of 376 . The distrust led to rebellion and battles which will not be described here. What is important to observe is that the conflict that lasted until the new peace treaty of 382 concerned the domination over the Thracian diocese, a large region which the Goths intended to take for themselves. This was

${ }^{20}$ Heather 1991, p. 123-128.

21 Socrates, IV. 33 (p. 187). 
not the case for the Pechenegs, who ravaged different areas, but did not manifest any will to settle elsewhere than in Patzinakia, or to conquer the provinces south of Haemus, even if they represented a threat for the control over these provinces. The first circumstance creating such threat was the alliance of Tyrach with the rebel general Leo Tornikes, who was fighting against the emperor Constantine IX in 1047. This alliance with the nomad "Scythians" was mentioned by John Mauropous in the speech of $29^{\text {th }}$ December $1047^{22}$. Later on, the rebellion of the elite force of the 15,000 Pechenegs which was sent against the Seljuq Turks ${ }^{23}$ led to a large uprising of the Pechenegs settled south of Haemus. However, the Byzantine army preserved the strategic initiative, despite some defeats, and the peace was concluded after four years in acceptable terms for the empire.

\section{Christianity}

A part of the Goths who crossed the Danube in the first movement were already Christians, Arians but also Orthodox. The persecution launched against the Church during the civil war in Gothia determined the Christian Fritigern to ask for military help from Valens in 372. The Christian faith of some of the Goths was a reason for searching a secure home in the empire, because the persecutions continued. They were the most willing to migrate, because they were in conflict with the majority of the Gothic society. They expected to be well received by their brothers in faith, the Romans, promising the conversion of all of them. Great expectations, that soon turned into disappointment. The second group of Goths, led by heathen chiefs, arrived from a more distant region where there are no proofs for the spread of Christianity. The Pechenegs were entirely heathen when they started the migration, but the colonization involved from the beginning the integration in the empire by mass conversion to Christianity. They were baptized in the waters of the Danube ${ }^{24}$, and thus the crossing of the frontier was symbolically associated with the admission in the Christian world. Kegen was the first to be baptized with the name of Ioannes (the name appears on his lead seals). Tyrach too became Christian when he was received by the emperor.

\section{Conclusion,}

Both migrations had disastrous effects for the empire, because the emperors were not able to foresee or to prevent the rebellions of these warrior people received as refugees. The need for supplementary population (farmers and soldiers) was the reason of both decisions to colonize the barbarians. Valens was preparing a

\footnotetext{
22 Iohannis Euchaitorum metropolitae, p. 192 (nr. 186).

23 Jean Skylitzès, Constantin Monomachos, 18 (p. 381).

24 Jean Skylitzès, Constantin Monomachos, 16 (p. 378).
} 
war against Persia, while Constantine IX was already in conflict with the eastern enemy of his time, the Seljuq Turks. Sending the Pecheneg soldiers in remote areas was intended not only to increase the forces on the eastern frontier, but also to prevent alliances with their brothers, which would happen if they remained, armed, near the Danubian frontier. However, arming a considerable part of the former Pecheneg prisoners was a big mistake, which led to a war that lasted four years, between 1049 and 1053. In the fourth century, Valens made a similar mistake when he believed that the agreement of 376 was enough to transform the refugees into faithful citizens. Instead of more economic and military resources, both the Goths and the Pechenegs caused much trouble in the South-East European provinces.

Ammianus Marcellinus, Histoire. Introduction, texte et traduction par Guy Sabbah, tome VI (Livres XXIX-XXXI, Index général). Paris: Les Belles Lettres, 1999

Atanasov, Georgi and Jordanov Ivan, Srednovekovnjat Vetren na Dunav. Šumen: 1994

Blockley, Roger, The Fragmentary Classicising Historians of the Later Roman Empire: Eunapius, Olympiodorus, Priscus and Malchus, vol. II. Liverpool: Francis Cairns, 1983

Cesa, Maria, "376-382: Romani e barbari sul Danubio", Studi urbinati. Seria B 3. Linguistica, letteratura, arte 57 (1984):63-99

Chauvot, Alain, Opinions romaines face aux barbares au IVe siècle ap. J.-C., Paris: De Boccard, 1998

Czeglédy, Karoly, "From East to West: The Age of Nomadic Migrations in Eurasia", Archivum Eurasiae Medii Aevi 3 (1983): 25-125

Curta, Florin, "The Image and Archaeology of the Pechenegs", Banatica, 23, 2013: 143202

Diaconu, Petre, Les Petchénègues au Bas-Danube, Bucarest: Editura Academiei, 1970

Dončeva-Petkova, Ljudmila, "Pečenezite v Dobrudža i Odărskite nekropoli (The Pechenegs in Dobruja and the necropolises Odartsi)", Dobrudža 24-25 (2013): $227-246$

Fiedler, Uwe, "Zur Suche nach dem archäologischen Niederschlag von Petschenegen, Uzen und Kumanen in den Gebieten südlich der unteren Donau". In The Steppe Lands and the World beyond them. Studies in honor of Victor Spinei on his 70th birthday, ed. F. Curta, B. P. Maleon, 249-286. Iaşi: Editura Universităţii "Alexandru Ioan Cuza", 2013

Heather, Peter, Goths and Romans, 332-489. Oxford: Clarendon Press, 1991

Histoire Auguste, tome V/1-2, texte établi, traduit et commenté par François Paschoud; Part. 2. Vies de Probus, Firmus, Saturnin, Proculus et Bonose, Carus, Numérien et Carin, ed. Paschoud, vol. V/2, Paris: Les Belles Lettres, 2001 
Iohannis Euchaitorum metropolitae, Quae in codice Vaticano Graeco 676 supersunt, Iohannes Bollig descripsit, Paulus de Lagarde edidit. Göttingen: 1882 (translated by Nicolae Şerban Tanaşoca in Fontes Historiae Daco-Romanae, vol. III, Bucureşti: Editura Academiei, 1975: 4/5, 10/11)

Jordanov, Ivan, Corpus of Byzantine Seals from Bulgaria, Volume 3. Sofia: National Archaeological Institute and Museum, 2009

Kulikovski, Michael, Rome's Gothic Wars. From the Third Century to Alaric. Cambridge: Cambridge University Press, 2007

Lenski, Noel, "The Gothic civil war and the date of the Gothic conversion", Greek, Roman and Byzantine Studies 36 (1995), 1: 51-87

Madgearu, Alexandru, Istoria militară a Daciei post-romane, 275-614. Târgovişte: Cetatea de Scaun, 2011

Malamut, Élisabeth, “L'image byzantine des Petchénègues”, Byzantinische Zeitschrift 88 (1995), 1: 105-147

Meško, Marek, "K vel'kosti pečenežských zoskupení (hôrd) na Balkáne v druhej polovici 11. storočia (On the Numerical Strength of Pecheneg Hordes in the Balkans during the Second Half of the 11th Century)", Byzantinoslovaca 4 (2012): 17-27

Meško, Marek, "Pecheneg groups in the Balkans (ca. 1053-1091) according to the Byzantine sources". In The Steppe Lands...: 179-206

Michael Psellus, The Chronographia. Translated from the Greek by E. R. A. Sewter. London: Routledge, 1953

Schmitt, Oliver, "Die Petschenegen auf dem Balkan von 1046 bis 1072”. In Pontos Euxeinos. Beiträge zur Archäologie und Geschichte des antiken Schwarzmeer- und Balkanraumes (Schriften des Zentrums für Archäologie und Kulturgeschichte des Schwarzmeerraumes, 10), 473-490. Langenweissbach: Beier \& Beran, 2006

Jean Skylitzès, Histoire des empereurs de Byzance, traduction française par B. Flusin, notes par J.-C. Cheynet. Paris: Lethielleux, 2003

Socrates: Socrates and Sozomenus Ecclesiastical Histories, trad. Philip Schaff (A Select Library of the Nicene and Post-Nicene Fathers of the Christian Church. Second Series, Translated into English with Prolegomena and Explanatory Notes, vol. II). New York: Christian Literature Publishing, 1886

Spinei, Victor, The Great Migrations in the East and South East of Europe from the Ninth to the Thirteenth Century. Amsterdam: Hakkert, 2006

Wirth, Gerhard, "Rome and its Germanic Partners in the Fourth Century". In Kingdoms of the Empire: The Integration of Barbarians in Late Antiquity (Transformation of the Roman World, 1), ed. W. Pohl, 13-55. Leiden: Brill, 1997

Wolfram, Herwig, History of the Goths. Berkeley: University of California Press, 1988 